PREGLEDNI RAD

UDK: 658.626:665.57

Mirta Anjoš, mag. oec. *

Doc. dr. sc. Irena Pandža Bajs *

\title{
ANALIZA DIMENZIJA PERCIPIRANE VRIJEDNOSTI I NJIHOVE POVEZANOSTI S NASLJEĐEM MARAKA
}

\author{
ANALYSIS OF PERCEIVED VALUE DIMENSIONS \\ AND ITS RELATIONSHIP WITH BRANDS HERITAGE
}

SAŽETAK: Na području marketinških istraživanja, marke s nasljeđem kao dijelom svoga identiteta, u posljednje vrijeme, privlače sve više interesa. Međutim, područje nasljeđa marke i njegovoga utjecaja na percipiranu vrijednost marke od strane potrošača te općenito na ponašanje potrošača, još uvijek je nedovoljno istraženo. Sukladno tome, cilj ovoga rada je odrediti odnos između nasljeđa marke i percipirane funkcionalne, emocionalne, ekonomske i socijalne vrijednosti marke. Istraživanje je provedeno na primjeru industrije parfema, u okviru koje su analizirane dvije marke parfema Chanel kao marke s nasljeđem te Bruno Banani kao marka bez nasljeđa. Navedena industrija je izabrana zbog visoke svjesnosti potrošača o podrijetlu i nasljeđu marki proizvoda koji joj pripadaju. Rezultati korelacija su pokazali pozitivnu povezanost bogatog nasljeđa marke s funkcionalnom i emocionalnom dimenzijom vrijednosti marke. Za razliku od marke s bogatim nasljeđem, ispitanici smatraju marku parfema bez bogatog nasljeđa isplativom i vrijednom svoje cijene, to jest percipiraju visoku ekonomsku vrijednost te marke.

KLJUČNE RIJEČI: nasljeđe marke, percipirana vrijednost za potrošača, industrija parfema.

ABSTRACT: In the area of marketing research, brands with a heritage as part of their brand identity has gained growing interest. Nevertheless, the study od brand heritage and its effects on customer perceived value and consumer behaviour is still insufficiently studied. Accordingly, the aim of this study is to define the brand heritage' impact on the value as perceived by the customer. The research was conducted on the example of the perfume industry. The perfume industry was chosen due to the high consumers awareness about the origin and heritage of the industry brands. The results showed the positive significant relationship between the brand heritage and the perceived functional value and positive relationship between the brand heritage and the perceived emotional value of the brand. On the other side, perfume brand without rich heritage is perceived as payable and worth of money.

KEYWORDS: brand heritage, customer perceived value, perfume industry. 


\section{UVOD}

U današnje vrijeme globalne ekonomije koju obilježavaju dinamičnost, nesigurnost i promjenjivo stanje na tržištima proizvoda i usluga, potrošači žele znati više o tvrtkama čije proizvode koriste te su u potrazi za autentičnosti i kredibilitetom, a to je duboko ukorijenjeno u nasljeđe tvrtke. Nasljeđe ima potencijal pružiti određena svojstva koja vrijednosti marke mogu dodati dubinu, autentičnost i vjerodostojnost (Aaker, 2004.). Tvrtke prožete bogatim nasljeđem posjeduju ključne elemente koji im pomažu preživjeti turbulentna vremena, pritom ih diferencirajući od konkurencije na jedinstven način (Urde i suradnici, 2007.). Također, uzmu li se u obzir potrošači koji nasljeđu marke pridaju velik značaj, ono može posljedično utjecati na povećanu lojalnost potrošača marki te spremnost da plati višu cijenu za nju. Današnja marketinška istraživanja pokazuju sve više zainteresiranosti za marke s nasljeđem kao dijelom svoga identiteta, za čimbenike koji uvjetuju nasljeđe marke, kao i za utjecaj koji nasljeđe marke ima na percipiranu vrijednost potrošača o marki i na kraju, ponašanje potrošača. Također, pojedina istraživanja su pokazala pozitivan utjecaj nasljeđa marke na dimenzije percipirane vrijednosti za potrošača (Wuestefeld i suradnici, 2011.). Navedeno područje istraživanja relativno je novo i prema tome nedovoljno istraženo. Na području Republike Hrvatske postoji nedostatak istraživanja koja se bave pitanjem važnosti nasljeđa marke kao dijela identiteta marke i njegovim utjecajem na percipirane vrijednosti za potrošača.

Cilj rada je istražiti percepciju potrošača o markama s nasljeđem u industriji i utvrditi postoji li povezanost nasljeđa marke s percepcijom potrošača o ekonomskoj, emocionalnoj, funkcionalnoj i socijalnoj vrijednosti maraka u industriji parfema. Industrija parfema je izabrana zbog visoke svjesnosti potrošača o podrijetlu i nasljeđu marki proizvoda koji joj pripadaju te je prema tome idealna za ovakvu vrstu istraživanja.

\section{KONCEPT PERCIPIRANE VRIJEDNOSTI}

\subsection{Pojam i definicija percipirane vrijednosti}

Percipirana vrijednost je apstraktan pojam čije značenje varira ovisno o kontekstu te različiti autori daju različite definicije percipirane vrijednosti potrošača. U marketingu, percipirana vrijednost je najčešće definirana sa stajališta potrošača. Kotler i Keller (2008.) percipiranu vrijednost za potrošača opisuju kao razliku između kupčeve procjene svih dobiti i svih troškova određene ponude i percepcije mogućih alternativa. Pritom, ukupnu vrijednost za kupca opisuju kao percipiranu vrijednost koju čini skup ekonomskih, funkcionalnih i psiholoških koristi koje kupac očekuje od određene tržišne ponude, dok ukupne troškove za kupca čini skup troškova koje kupac očekuje tijekom procjene, nabave, upotrebe i raspolaganja dobivenom tržišnom ponudom, uključujući i novčani, vremenski, energijski i psihološki trošak.

Koncept percipirane vrijednosti za potrošača je područje interesa koje se počelo intenzivnije razvijati 90-ih godina prošloga stoljeća, kako na akademskoj, tako i na poslovnoj razini (Lin i suradnici, 2005., u Pandža Bajs, 2012.). O važnosti percipirane vrijednosti za potrošača govori činjenica da je prepoznata kao temelj svih marketinških aktivnosti te kao kritično strateško sredstvo za privlačenje i zadržavanje gostiju (Holbrook, 1999., Lee i suradnici, 2004.., u Pandža Bajs, 2012.). Piri Rajh (2012.) navodi da dosadašnja istraživanja 
percipiranu vrijednost promatraju kao varijablu koja se formira pod utjecajem percepcije kvalitete proizvoda i percepcije (novčanog) troška ili kao varijablu na koju utječe potrošačeva percepcija rizika.

Prema Zeithaml (1988.), percipirana vrijednost za potrošača je potrošačeva ukupna procjena korisnosti proizvoda ili usluge temeljena na percepcijama onoga što je potrošač dao i što je dobio zauzvrat. Prema značajnom broju relevantnih autora (Dodds, Monroe i Grewal, 1990.; McDougall i Levesque, 2000.; Lapierre, 2000.; Woodal, 2003.) percipirana vrijednost za potrošača se analizira kao odnos između koristi i troškova ili između kvalitete i troškova. Na drugoj strani autori kao Sheth i suradnici (1991.), Sweeney i Soutar (2001.), Roig i suradnici (2006.) uključuju koncept višedimenzionalnosti percipirane vrijednosti prema kojemu percipirana vrijednost daje sumu različitih dimenzija vrijednosti koje imaju različiti utjecaj u različitim situacijama.

\subsection{Dimenzije percipirane vrijednosti}

Prema mnogim istraživanjima, konceptu percipirane vrijednosti za potrošača pristupa se na dva načina. Prvi pristup objašnjava da se percipirana vrijednost sastoji od dvije komponente, a to su komponenta koristi (ekonomska, socijalna, odnosna) te troškovna komponenta (cijena, vrijeme, trud i rizik) (Sunthorncheewin i suradnici, 2013.).

Mnogi autori kao što su Woodruff, De Ruyte i suradnici, Sweeney i Soutar, Sanchez i suradnici (u Roig i suradnici, 2006.) navode da se drugi pristup temelji na multidimenzionalnom konceptu percipirane vrijednosti potrošača koji se sastoji od dvije glavne dimenzije: kognitivne, koja je uglavnom vezana uz ekonomske vrijednosti glavnog proizvoda ili usluge te, afektivne, koja obuhvaća socijalnu i emocionalnu vrijednost proizvoda.

Khan i Kadir (2011.) objašnjavaju da se percipirana vrijednost ne bi trebala promatrati kao ishod jedne vrijednosti koja je rezultat razlike između koristi i troškova, već da je percipirana vrijednost kompleksna, zbog čega bi se trebala promatrati kao multidimenzionalna vrijednost. Sweeney i Soutar (2001.) su u svome istraživanju percipirane vrijednosti identificirali dimenzije percipirane vrijednosti kao što su kvaliteta, emocionalna, cjenovna te socijalna vrijednost. Seth i suradnici (1991.) su predložili pet dimenzija percipirane vrijednosti: socijalna, funkcionalna, emocionalna, uvjetovana te spoznajna dimenzija. Spoznajna dimenzija odnosi se na svojstvo proizvoda ili usluge da pruži potrošaču određenu novu spoznaju (novo znanje) odnosno pobudi znatiželju ili zadovolji želju za znanjem potrošača, dok se uvjetovana dimenzija odnosi na skup situacija s kojima se potrošač suočava prilikom donošenja odluke o kupnji. (Sheth i suradnici, 1991.). Sweeney i Soutar (2001.) su smatrali da spoznajna i uvjetovana dimenzija nisu bitne, stoga su pet početnih dimenzija reducirali na tri dimenzije te osmislili ljestvicu za mjerenje vrijednosti zvanu PERVAL koja se temelji na funkcionalnoj, socijalnoj i emocionalnoj vrijednosti. Funkcionalna dimenzija vrijednosti odnosi se na značajke poput cijene (vrijednosti za novac), kvalitete (percipirane kvalitete i očekivanog prinosa od proizvoda ili usluge) te prilagodljivosti (upotrebljivosti i praktičnosti proizvoda), dok se socijalna i emocionalna komponenta odnose na nematerijalne karakteristike (Sweeney i Soutar, 2001., Roig i suradnici, 2006.).

Općenito, većina autora koji su koncept percipirane vrijednosti potrošača promatrali kao multidimenzionalni koncept, slažu se da se njegove dimenzije mogu podijeliti u dva smje- 
ra, dimenzije funkcionalnog karaktera i dimenzije emocionalnog ili afektivnog karaktera. Prema radovima relevantnih autora iz tog područja kao što su Sheth, Ulaga, Woodall, Holbrooka i drugi, Wuestefeld i suradnici (2012.) su izdvojili četiri glavne dimenzije percipirane vrijednosti potrošača: ekonomska, funkcionalna, emocionalna te socijalna vrijednost.

\subsubsection{Ekonomska dimenzija percipirane vrijednosti}

Ekonomska dimenzija percipirane vrijednosti za potrošača se odnosi na novčani aspekt proizvoda, kao što su cijena, preprodajna cijena, popusti, ulaganja i slično (Smith i Colgate, 2007.). Navedena dimenzija se odnosi na vrijednost novca izraženoga u novčanoj valuti koja je utrošena kako bi se dobio određeni proizvod. Također, slično poduzećima, potrošači pokušavaju smanjiti troškove i ostala davanja koja je potrebno utrošiti u kupovinu, vlasništvo te korištenje proizvoda. Pandža Bajs (2012.) ističe kako potrošači pri procjeni vrijednosti ponude ne pridaju istu važnost svim vrstama troškova odnosno pojedini potrošači u obzir uzimaju vrijeme koje je potrebno uložiti, dok drugi veću važnost pridaju riziku da ponuda neće ispuniti očekivane koristi.

Šapić i suradnici (2014.) ističu da potrošači ekonomsku vrijednost određuju temeljem usporedbe koristi koje dobivaju od proizvoda ili usluge i troškova neophodnih za njihovo pribavljanje. Također, napominje kako su suvremeni potrošači sve oprezniji tijekom procesa kupovine i žele za vlastiti uloženi novac dobiti što veću vrijednost. Sveukupno, prema Wuestefeldu i suradnicima (2012.), ekonomska dimenzija percipirane vrijednosti se odnosi na sljedeće troškove:

- Novčani troškovi, poput cijene proizvoda ili usluge

- Psihološki troškovi, poput kognitivnih poteškoća i stresa, troškova pretraživanja, troškova učenja te razni ostali psihološki uvjetovani troškovi

- Osobna ulaganja potrošača, trud te energija uložena u procesu kupovine i konzumacije proizvoda ili usluge

- Rizik, poput financijskog i funkcionalnog rizika.

\subsubsection{Funkcionalna dimenzija percipirane vrijednosti}

Funkcionalna dimenzija percipirane vrijednosti za potrošača se odnosi na dobiti i koristi poput kvalitete, jedinstvenosti, upotrebljivosti, pouzdanosti i trajnosti određenog proizvoda ili usluge (Sheth i suradnici, 1991.). Općenito, proizvod je osmišljen je za obavljanje određene funkcije s ciljem zadovoljavanja potreba potrošača, a definiran je određenim fizičko-kemijskim te konkretnim ili apstraktnim karakteristikama.

Funkcionalna vrijednost kao dimenzija percipirane vrijednosti obuhvaća tri ključna aspekta (Woodruff, 1997., u Wuestefeld i suradnici, 2012.):

- Točne, precizne ili odgovarajuće značajke, funkcije ili karakteristike (kao što je kvaliteta, estetika, prilagodba ili kreativnost)

- Odgovarajuću izvedbu (kao što su pouzdanost, kvaliteta izvedbe ili usluga podrške potrošaču)

- Odgovarajući rezultati ili posljedice korištenja proizvoda. 


\subsubsection{Emocionalna dimenzija percipirane vrijednosti}

Emocionalna dimenzija percipirane vrijednosti može se definirati kao dimenzija koja se odnosi na iskustva, osjećaje i emocije koje pojedine marke proizvoda ili proizvodi pružaju potrošačima (Sheth i suradnici, 1991.). Značajan je utjecaj emocija na percepciju vrijednosti, a očekivane emocionalne koristi mogu imati utjecaj na odabir među ponuđenim alternativama (Moliner i sur., 2007.; Sanchez i suradnici, 2006.) Također, bitno je uzeti u obzir i emotivnu reakciju potrošača u razdoblju nakon kupovine.

Wuestefeld i suradnici (2011., 2012.) u svojim radovima su se bavili luksuznim proizvodima te ističu da luksuzni proizvodi posebice pružaju subjektivne i neopipljive koristi. Istraživanja su pokazala da su emocionalne reakcije, poput osjetilnog užitka i zadovoljstva, estetske ljepote ili uzbuđenja, povezane s luksuznom potrošnjom. Westbrook i Oliver (1991., u Wuestefeld i suradnici, 2012.) objašnjavaju da se afektivna vrijednost odnosi na percipiranu subjektivnu korist te istinski zadovoljavajuća svojstva stečena kupovinom i potrošnjom marke proizvoda koja budi osjećaje i afektivna stanja. Emocionalna vrijednost kao dimenzija percipirane vrijednosti predstavlja emocionalnu korist koju potrošač ima od proizvoda, a koja se temelji na osjećajima ili na afektivnim doživljajima tog proizvoda (Abdolvand i Andervazh, 2011.).

\subsubsection{Socijalna dimenzija percipirane vrijednosti}

Socijalna dimenzija percipirane vrijednosti se povezuje s jednom ili više društvenih skupina odnosno objašnjava da proizvod ili usluga ostvaruje svoju socijalnu vrijednost kroz pozitivnu ili negativnu povezanost s različitim društvenim skupinama (Sheth i suradnici, 1991.). Pored osobnog značenja pojedinog proizvoda ili marke za potrošača, veliko značenje imaju i prestiž, status ili imidž određenog proizvoda ili usluge (Vigneron i Johnson, 2004.). Tako, primjerice, potrošnju luksuznih dobara obilježava snažna socijalna komponenta.

Li i suradnici (2005.) istraživali su povezanost potrošačeve zabrinutosti o vlastitome statusu i potrošnji luksuznih dobara na primjeru potrošača u kineskome društvu. U svome radu, navode bitnu ulogu socijalne dimenzije percipirane vrijednosti jer potrošači sa snažnom potrebom isticanja statusa u društvu teže kupovini fizičkih dobara i usluga (primjerice, odjeće određenih marki i satova) koja će im omogućiti prestiž i dobar status u društvu.

Bergami i Bogazzi (2000. u Šapić i suradnici, 2014.) ističu prestiž kao jednu od ključnih odrednica percipirane vrijednosti jer prestiž kao dio socijalne vrijednosti podrazumijeva da je percepcija potrošača pod jakim utjecajem ljudi čije se mišljenje vrednuje i poštuje i koji određene proizvode ili usluge promatraju kao statusni simbol. Prestiž određenog proizvoda ili usluge dovodi do identifikacije potrošača s njima odnosno kroz korištenje prestižnih proizvoda i/ili usluga stvara se osjećaj ostvarivanja vlastite osobnosti (Bergami i Bogazzi, 2000., u Šapić i suradnici, 2014.). 


\section{NASLJEĐE MARKE I NJEGOV UTJECAJ NA PERCIPIRANU VRIJEDNOST MARKE KOD POTROŠAČA}

\subsection{Definiranje nasljeđa marke}

Marke s nasljeđem, stvorene i njegovane desetljećima ili čak stoljećima, imale su vremena izgraditi značajnu prošlost (Aaker, 1996.). Prema Aakeru (2004.) posjedovanje nasljeđa pomaže marki biti relevantna u sadašnjosti i perspektivna u budućnosti te takvu marku prožetu nasljeđem obilježavaju autentičnost, vjerodostojnost i povjerenje što može osigurati snagu marki, osobito na međunarodnome tržištu.

Koncept nasljeđa marke promatra se kao dio identiteta marke te se definira kao „dimenzija identiteta marke koja se temelji na njezinoj vjerodostojnosti, dugovječnosti, temeljnim vrijednostima, korištenju simbola te posebice u uvjerenju poduzeća da je njegova povijest značajna“ (Urde i suradnicima, 2007.). Prema tome, marke s nasljeđem predstavljaju različitu kategoriju marki te zahtijevaju specifičan pristup od strane menadžmenta određenog poduzeća. Poduzeće, da bi posjedovalo marku s nasljeđem, mora naglasiti nasljeđe kao ključnu komponentu identiteta marke i njezinoga pozicioniranja.

Nasljeđe je važan pokretač vrijednosti, posebice za korporativne marke, s obzirom da rani korijeni dodaju marki autentičnost i diferencijaciju, stoga je kapital takvih marki iznimno jak, a nasljeđe pomaže definiranju marki u sadašnjosti te im dodaje vrijednost (Aaker, 2004., u Wuestefeld i suradnici, 2011.).

Nadalje, Baldinger i suradnici (1996.) naglašavaju da se poduzeće ne mora vratiti u prošlost da bi posjedovalo nasljeđe. Ono može biti moderno i inovativno, a pritom izražavati svoje nasljeđe odnosno poduzeća bi trebala koristiti nasljeđe kao konkurentsku prednost s ciljem diferencijacije i izgradnje marke koja je vrijedna za dionike i potrošače.

\subsection{Utjecaj nasljeđa marke na potrošačevu percipiranu vrijednost marke i ponašanje potrošača}

Urde i suradnici (2007.) u svome istraživanju objašnjavaju da nasljeđe marke dodaje asocijacije dubine, autentičnosti i vjerodostojnosti percipiranoj vrijednosti marke. Pored toga, kao temelj za diferencijaciju pri pozicioniranju, nasljeđe je korisno za izgradnju posebnog odnosa s potrošačima i ostalim interesnim skupinama. Dakle, kao konkurentska prednost, uzevši u obzir potrošače kojima je nasljeđe od značajne važnosti, nasljeđe marke može rezultirati spremnošću kupca da prihvati veću cijena proizvoda te većom lojalnošću potrošača.

Autori Wuestefeld, Hennings, Schmidt i Wiedmann (2011., 2012.) proveli su nekoliko istraživanja koja povezuju nasljeđe marke i percipiranu vrijednost marke te ponašanja potrošača. Temeljem njih, došli su do zaključka da marke s nasljeđem potrošačima pružaju i potvrđuju njihova očekivanja vezana za budućnost marke te im daju obećanje da se marka neće mijenjati u budućnosti, već će nastaviti isporučivati jednake vrijednosti. Iz toga razloga, nasljeđe marke povećava percipiranu vrijednost marke, pozitivno utječe na cjelokupan imidž marke u očima potrošača te može umanjiti potrošačev percipirani rizik.

Buss (2007. u Baum, 2011.) je temeljem svojih istraživanja došao do spoznaje pozitivnog utjecaja nasljeđa marke na ponašanje potrošača, na njihovu lojalnost. Njegovo istraži- 
vanje je pokazalo i da potrošači pridaju više povjerenja markama s nasljeđem, posebice u vremenima nesigurnosti.

Ipak, u svome radu, Liebrenz - Himes i suradnici (2007.) navode da marke s nasljeđem iako imaju određene prednosti, susreću se s problemima vezanima za godine postojanja te se bave pitanjem kako dugotrajno održati lojalnost potrošača. Kao rješenje za marku, da bi ona ostala održiva, navedeni autori navode obvezu poduzeća njegovati vrijednosti marke te biti dosljedan u svakome trenutku, kako unutar poduzeća, tako i izvan. Svaki zaposlenik trebao bi biti ambasador marke te bi sve dodirne toče marke s potrošačima trebale zajedno tvoriti jednu cjelinu s ciljem pružanja potrošačima jedinstvenog iskustva (Baum, 2011.). Kod marki s nasljeđem javlja se potreba kontinuirane analize i promišljenoga ulaganja u marku kako ona ne bi postala irelevantna, izvan svoga vremena. Marke s nasljeđem trebaju održavati komunikaciju s potrošačima, pratiti trendove te potrošačima pružati pogodnosti u skladu s njima. Ako se to ne ispuni, padanje u zaborav često postaje stvarnost marki s nasljeđem, neovisno o njihovome povijesnom nasljeđu (Urde i suradnici, 2007.).

\section{ISTRAŽIVANJE DIMENZIJA PERCIPIRANE VRIJEDNOSTI I NASLJEĐA MARKE U INDUSTRIJI PARFEMA}

\subsection{Ciljevi istraživanja}

U radu se nastoje istražiti percepcije potrošača o markama s nasljeđem te utvrditi postoji li povezanost nasljeđa marke i percepcije potrošača o ekonomskoj, funkcionalnoj, emocionalnoj i socijalnoj vrijednosti kao dimenzijama percipirane vrijednosti marke. Industrija parfema je izabrana zbog visoke svjesnosti potrošača o podrijetlu i nasljeđu marki proizvoda koji joj pripadaju. U odnos su stavljene dvije marke parfema: Chanel i Bruno Banani. Marka Chanel izabrana je kao predstavnica marki s nasljeđem, dok marka Bruno Banani predstavlja marke bez nasljeđa. Cilj istraživanja je ispitati prepoznaju li potrošači elemente nasljeđa marke kod navedenih marki, utvrditi stavove potrošača o dimenzijama percipirane vrijednosti marki parfema Chanel i Bruno Banani te, na kraju, utvrditi povezanost između postojanja nasljeđa marke i dimenzija percipirane vrijednosti marke (funkcionalne, emocionalne, ekonomske, socijalne).

\subsection{Metodološki okvir istraživanja}

Istraživanje je provedeno na uzorku od 100 ispitanika na području Republike Hrvatske. S ciljem što kvalitetnijega i efikasnijega prikupljanja rezultata istraživanja, istraživanje je provedeno pomoću dvije metode prikupljanja podataka. Do jednoga dijela ispitanika došlo se slanjem anketnoga upitnika putem mail-a, dok se do drugoga dijela ispitanika došlo osobnim ispitivanjem. Da bi mogli sudjelovati u istraživanju ispitanici su trebali biti upoznati s istraživanim markama ili imati iskustvo u kupovini istih. Instrument kvantitativnog istraživanja je anketni upitnik, u okviru kojega se koristila Likertova ljestvica. Upitnik je kreiran po uzoru na anketne upitnike u radovima Wuestefeld, Hennigs, Schmidt i Wiedmann (2011.) godine te Ali (2007.). 
Tablica 1: Obilježja ispitanika

\begin{tabular}{|c|c|}
\hline Struktura uzorka & Postotak \\
\hline \multicolumn{2}{|l|}{ Spol ispitanika } \\
\hline muški & $40 \%$ \\
\hline ženski & $60 \%$ \\
\hline \multicolumn{2}{|l|}{ Dob ispitanika } \\
\hline $18-25$ & $23 \%$ \\
\hline $26-30$ & $30 \%$ \\
\hline $31-35$ & $18 \%$ \\
\hline $36-40$ & $11 \%$ \\
\hline $41-45$ & $9 \%$ \\
\hline $46-50$ & $4 \%$ \\
\hline Više 51 & $5 \%$ \\
\hline \multicolumn{2}{|l|}{ Stručna sprema } \\
\hline srednja škola & $22 \%$ \\
\hline viša škola & $40 \%$ \\
\hline fakultet & $32 \%$ \\
\hline magistarski ili doktorski studiji & $6 \%$ \\
\hline \multicolumn{2}{|l|}{ Radni status } \\
\hline đak/student & $28 \%$ \\
\hline zaposlen & $47 \%$ \\
\hline nezaposlen & $18 \%$ \\
\hline umirovljenik & $6 \%$ \\
\hline ostalo & $1 \%$ \\
\hline \multicolumn{2}{|l|}{ Mjesečni prihodi kućanstva } \\
\hline do $3.000 \mathrm{kn}$ & $7 \%$ \\
\hline $3.001-6.000 \mathrm{kn}$ & $31 \%$ \\
\hline $6.001-9.000 \mathrm{kn}$ & $30 \%$ \\
\hline $9.001-12.000 \mathrm{kn}$ & $21 \%$ \\
\hline $12.001-15.000 \mathrm{kn}$ & $9 \%$ \\
\hline više od 15.000 kn & $2 \%$ \\
\hline Total & $100 \%$ \\
\hline
\end{tabular}

Izvor: rezultati istraživanja.

Prvi dio upitnika sastoji se od 21 tvrdnje vezane za marku Chanel. Prvih 9 tvrdnji preuzeto je iz istraživanja Wuestefelda i suradnika iz 2012. godine te se odnosi na istraživanje nasljeđa marke odnosno pomoću njih se želi utvrditi percipiraju li ispitanici marku Chanel kao marku s nasljeđem. Sljedećih 12 tvrdnji preuzeto je iz rada autora Ali iz 2007. godine. Tvrdnje su korištene kako bi se utvrdile percepcije potrošača o funkcionalnoj, ekonomskoj, 
emocionalnoj i socijalnoj dimenziji percipirane vrijednosti marke Chanel. Od ispitanika je traženo da za prvu grupu tvrdnji izraze stupanj slaganja na Likertovoj ljestvici od pet stupnjeva (1 - u potpunosti se ne slažem do 5 - u potpunosti se slažem).

Drugi dio upitnika stavlja pred ispitanike identične 21 tvrdnje kao iz prvoga dijela upitnika, samo se one u ovome dijelu odnose na marku Bruno Banani. Sve tvrdnje su prilagođene potrebama istraživanja, to jest modificirane su u skladu s industrijom kojoj pripadaju marke koje su predmet istraživanja te su prilagođene kako bi bile u duhu hrvatskoga jezika. Kao u prethodnome dijelu upitnika i ovdje su ispitanici na Likertovoj ljestvici od pet stupnjeva morali odrediti stupanj vlastitoga slaganja odnosno neslaganja s pojedinom tvrdnjom (ocjena 1 označava - u potpunosti se ne slažem, dok ocjena 5 označava - u potpunosti se slažem).

Treći, ujedno i posljednji dio upitnika odnosi se na demografske podatke ispitanika: dob, spol, stručna sprema, radni status te prihodi kućanstva.

Prema rezultatima istraživanja (tablica 1.) najveći broj ispitanika je ženskoga spola (60\%), najčešća dobna skupina ispitanika je 26 - 30 god. (30\%). Također, najveći broj ispitanika je zaposlen (47\%) s najčešćim mjesečnim prihodima kućanstva u kategoriji od 3.001 $-6.000 \mathrm{kn}(31 \%)$.

\subsection{Rezultati istraživanja}

U analizi odgovora vezanih za nasljeđe marki parfema Chanel i marke Bruno Banani, jasno su vidljive razlike u percepcijama marki odnosno vidljivo je da ispitanici prepoznaju da marku parfema Chanel obilježava duga prošlost i bogato nasljeđe, dok je marka Bruno Banani marka s relativno kratkom povijesti čiji identitet ne upotpunjuje bogato nasljeđe.

Tablica 2. Analiza nasljeđa za marke Chanel i Bruno Banani

\begin{tabular}{|l|l|c|c|c|c|}
\hline \multicolumn{2}{|l|}{ Tvrdnje vezane za nasljeđe marke } & \multicolumn{2}{c|}{ Chanel } & \multicolumn{2}{c|}{ Bruno Banani } \\
\cline { 2 - 6 } & $\begin{array}{c}\text { Aritmetička } \\
\text { sredina }\end{array}$ & $\begin{array}{c}\text { Standardna } \\
\text { devijacija }\end{array}$ & $\begin{array}{c}\text { Aritmetička } \\
\text { sredina }\end{array}$ & $\begin{array}{c}\text { Standardna } \\
\text { devijacija }\end{array}$ \\
\hline 1. & Marka parfema povezuje se s pojmom uspješnosti. & 4.02 & 1.00 & 2.35 & 1.23 \\
\hline 2. & $\begin{array}{l}\text { Marka parfema postavlja visoke kriterije za ostale } \\
\text { marke parfema. }\end{array}$ & 3.86 & 0.81 & 2.22 & 0.92 \\
\hline 3. & Marka parfema promovira određen stil života. & 3.85 & 1.10 & 2.45 & 1.13 \\
\hline 4. & $\begin{array}{l}\text { Vrlo dobro sam upoznat/a s navedenom markom } \\
\text { parfema. }\end{array}$ & 3.47 & 1.14 & 2.42 & 1.09 \\
\hline 5. & Marka parfema ima snažno kulturno značenje. & 3.85 & 1.25 & 1.80 & 0.78 \\
\hline 6. & Marka parfema je jako poznata marka u društvu. & 4.05 & 0.86 & 2.51 & 1.18 \\
\hline 7. & Marka parfema ima snažan identitet. & 4.02 & 0.83 & 2.15 & 1.01 \\
\hline 8. & $\begin{array}{l}\text { Marka parfema je jedinstvena u odnosu na ostale } \\
\text { marke parfema. }\end{array}$ & 4.22 & 0.81 & 2.14 & 0.95 \\
\hline 9. & $\begin{array}{l}\text { Marka parfema ima vrlo dobru reputaciju u odnosu na } \\
\text { ostale marke parfema. }\end{array}$ & 4.36 & 0.84 & 2.77 & 1.20 \\
\hline
\end{tabular}

Izvor: rezultati istraživanja. 
Ispitanici pridaju marki Chanel značajke poput uspješnosti, snažnog kulturnog značenja, prepoznatljivosti u društvu, izvrsne reputacije, snažnog identiteta koje su ujedno i sastavnice elemenata samog nasljeđa marke, dok nemaju pozitivan stav prema marki Bruno Banani u kontekstu nasljeđa marke.

Analiza funkcionalne dimenzije percipirane vrijednosti prikazuje da se ispitanici slažu da marku Chanel obilježavaju izvanredna kvaliteta, pouzdanost i konzistentnost (tablica 3.). Aritmetičke sredine odgovora vezanih za marku Bruno Banani nalaze se u neutralnome području prema blago pozitivnom stavu o marki. Uspoređujući odgovore za marku Chanel s odgovorima za marku Bruno Banani vidljive su razlike u percipiranim vrijednostima potrošača vezanima za funkcionalnost odnosno kvalitetu pojedine marke. Pri tome, marku parfema Chanel percipiraju kao kvalitetnu marku, dok za marku parfema Bruno Banani imaju neutralan stav o njegovoj kvaliteti.

Tablica 3. Funkcionalna dimenzija percipirane vrijednosti marki Chanel i Bruno Banani

\begin{tabular}{|l|l|c|c|c|c|}
\hline \multicolumn{2}{|c|}{ Tvrdnja } & \multicolumn{2}{c|}{ Chanel } & \multicolumn{2}{c|}{ Bruno Banani } \\
\cline { 3 - 6 } & $\begin{array}{c}\text { Aritmetička } \\
\text { sredina }\end{array}$ & $\begin{array}{c}\text { Standardna } \\
\text { devijacija }\end{array}$ & $\begin{array}{c}\text { Aritmetička } \\
\text { sredina }\end{array}$ & $\begin{array}{c}\text { Standardna } \\
\text { devijacija }\end{array}$ \\
\hline 1. & Parfem navedene marke je izvanredne kvalitete. & 4.03 & 0.98 & 3.42 & 1.17 \\
\hline 2. & Parfem navedene marke karakterizira pouzdanost. & 3.84 & 0.94 & 3.40 & 1.02 \\
\hline 3. & $\begin{array}{l}\text { Parfem navedene marke je vrlo konzistentne } \\
\text { kvalitete. }\end{array}$ & 3.88 & 1.09 & 3.26 & 1.18 \\
\hline
\end{tabular}

Izvor: rezultati istraživanja.

Analiza ekonomske dimenzije percipirane vrijednosti marki parfema Chanel pokazuje da ispitanici smatraju da marka parfema Chanel ne pruža dobar omjer cijene i kvalitete, nije isplativa niti je vrijedna svoje cijene (tablica 4.). Suprotno tim rezultatima, analiza odgovora za marku parfema Bruno Banani pokazuje pozitivan stav ispitanika o navedenim tvrdnjama odnosno ispitanici se slažu da je marka parfema Bruno Banani isplativa, vrijedna svoje cijene te da pruža dobar omjer cijene i kvalitete.

Tablica 4. Ekonomska dimenzija percipirane vrijednost marki Chanel i Bruno Banani

\begin{tabular}{|l|l|c|c|c|c|}
\hline \multicolumn{2}{|c|}{ Tvrdnja } & \multicolumn{2}{c|}{ Chanel } & \multicolumn{2}{c|}{ Bruno Banani } \\
\cline { 3 - 6 } & $\begin{array}{c}\text { Aritmetička } \\
\text { sredina }\end{array}$ & $\begin{array}{c}\text { Standardna } \\
\text { devijacija }\end{array}$ & $\begin{array}{c}\text { Aritmetička } \\
\text { sredina }\end{array}$ & $\begin{array}{c}\text { Standardna } \\
\text { devijacija }\end{array}$ \\
\hline 1. & $\begin{array}{l}\text { Parfem navedene marke pruža dobar omjer cijene } \\
\text { i kvalitete. }\end{array}$ & 2.62 & 1.17 & 3.85 & 1.11 \\
\hline 2. & Parfem navedene marke je isplativ. & 2.51 & 1.23 & 3.88 & 1.14 \\
\hline 3. & Parfem navedene marke je vrijedan svoje cijene & 2.67 & 1.30 & 3.87 & 1.16 \\
\hline
\end{tabular}

Izvor: rezultati istraživanja. 
Analiza emocionalne dimenzije percipirane vrijednosti prikazuje pozitivan stav ispitanika o tvrdnjama da marka Chanel pruža osjećaj zadovoljstva, oduševljenja i radosti (tablica 5.). Nadalje, aritmetičke sredine odgovora koji se odnose na marku parfema Bruno Banani pripadaju neutralnoj zoni koja teži zoni neslaganja s navedenim tvrdnjama, pri tome je najlošije ocijenjena tvrdnja koja povezuje marku parfema Bruno Banani s osjećajem oduševljenja.

Tablica 5. Emocionalna dimenzija percipirane vrijednosti marki Chanel i Bruno Banani

\begin{tabular}{|l|l|c|c|c|c|}
\hline \multicolumn{2}{|c|}{ Tvrdnja } & \multicolumn{2}{c|}{ Chanel } & \multicolumn{2}{c|}{ Bruno Banani } \\
\cline { 3 - 6 } & $\begin{array}{c}\text { Aritmetička } \\
\text { sredina }\end{array}$ & $\begin{array}{c}\text { Standardna } \\
\text { devijacija }\end{array}$ & $\begin{array}{c}\text { Aritmetička } \\
\text { sredina }\end{array}$ & $\begin{array}{c}\text { Standardna } \\
\text { devijacija }\end{array}$ \\
\hline 1. & Parfem navedene marke pruža zadovoljstvo. & 3.92 & 1.05 & 2.81 & 1.14 \\
\hline 2. & Parfem navedene marke pruža osjećaj oduševljenja. & 4.03 & 1.11 & 2.70 & 1.18 \\
\hline 3. & Parfem navedene marke pruža osjećaj radosti. & 4.02 & 1.05 & 2.73 & 1.20 \\
\hline
\end{tabular}

Izvor: rezultati istraživanja.

Socijalna dimenzija percirane vrijednosti marki parfema Chanel i Bruno Banani se analizira kroz cijenjenost marke od strane potrošača, mogućnost koju marke pružaju potrošačima izraziti vlastiti identitet i osobnost u društvu te prihvaćenost od strane obitelji i bliskih prijatelja (tablica 6.). Odgovori ispitanika na navedene tvrdnje koje se odnose na marku Chanel upućuju na pozitivan stav ispitanika, pri čemu se uviđa da potrošači cijene tu marku (4.06), da marka omogućava izražavanje osobnosti u društvu te prihvaćanje od strane društva. Takvi odgovori ispitanika upućuju na percepciju potrošača o visokoj socijalnoj vrijednosti marke Chanel. Analiza odgovora vezanih za marku parfema Bruno Banani pokazuju da potrošači imaju neutralan stav o socijalnoj vrijednosti te marke.

Tablica 6. Socijalna dimenzija percipirane vrijednosti marki Chanel i Bruno Banani

\begin{tabular}{|l|l|c|c|c|c|}
\hline \multicolumn{2}{|c|}{ Tvrdnja } & \multicolumn{2}{c|}{ Chanel } & \multicolumn{2}{c|}{ Bruno Banani } \\
\cline { 3 - 6 } & $\begin{array}{c}\text { Aritmetička } \\
\text { sredina }\end{array}$ & $\begin{array}{c}\text { Standardna } \\
\text { devijacija }\end{array}$ & $\begin{array}{c}\text { Aritmetička } \\
\text { sredina }\end{array}$ & $\begin{array}{c}\text { Standardna } \\
\text { devijacija }\end{array}$ \\
\hline 1. & $\begin{array}{l}\text { Parfem navedene marke je vrlo cijenjen od strane } \\
\text { potrošača. }\end{array}$ & 4.06 & 0.90 & 2.93 & 1.21 \\
\hline 2. & $\begin{array}{l}\text { Parfem navedene marke omogućuje potrošaču izraziti } \\
\text { vlastiti identitet i osobnost u društvu. }\end{array}$ & 3.98 & 0.91 & 2.94 & 1.18 \\
\hline 3. & $\begin{array}{l}\text { Korisnici parfema navedene marke su pozitivno } \\
\text { prihvaćeni od strane obitelji i bliskih prijatelja. }\end{array}$ & 3.97 & 0.88 & 3.12 & 1.13 \\
\hline
\end{tabular}

Izvor: rezultati istraživanja.

S ciljem utvrđivanja postoji li povezanost nasljeđa marke Chanel i dimenzija percipiranih vrijednosti potrošača navedene marke, izračunate su korelacije između navedenih 
varijabli u programu SPSS. Za provjeru normalnosti distribucija svih rezultati varijabli mjerenih u ovome istraživanju, proveden je Kolmogorov-Smirnoljev test, kojime se pokazalo odstupanje dobivene distribucije od normalne, stoga je u obradi podataka korištena neparametrijska analiza odnosno Spearmanov koeficijent korelacije. Koeficijent determinacije, tj. jačine linearne povezanosti se može računati samo kod Pearsonove korelacije stoga se u ovome slučaju mogu analizirati samo korelacije između istraživanih varijabli.

Tablica 7. Rezultati korelacija između varijabla nasljeđa marke Chanel i dimenzija percipirane vrijednosti potrošača za marku Chanel

\begin{tabular}{|l|c|}
\hline Dimenzije percipirane vrijednosti & $\begin{array}{c}\text { Korelacija s nasljeđem } \\
\text { marke Chanel }\end{array}$ \\
\hline Funkcionalna dimenzija vrijednosti marke Chanel & $\mathrm{r}=0.216$ \\
$\mathrm{P}=0.031 *$ \\
$\mathrm{~N}=100$
\end{tabular}

Legenda: $\mathrm{r}-$ Spearmanov koeficijent korelacije, * $\mathrm{P}<0.05$, ** $\mathrm{P}<0.01$. Izvor: rezultati istraživanja.

Rezultati prikazani u tablici 7. prikazuju povezanost nasljeđa marke Chanel i dimenzija percipiranih vrijednosti potrošača za marku Chanel. Iz rezultata korelacije između varijabli nasljeđa marke i funkcionalne dimenzije percipirane vrijednosti marke Chanel vidljivo je da Spearmanov koeficijent korelacije (r) iznosi 0.216, dok značajnost koeficijenta korelacije (P) iznosi 0.031. S obzirom da je značajnost koeficijenta korelacije manja od 0.05, ( $\mathrm{P}<0.05)$, može se zaključiti da ukazuje na postojanje povezanosti između varijabli nasljeđa marke i funkcionalne dimenzije percipirane vrijednosti marke Chanel. Iz Spearmanovog koeficijenta vidljivo je postojanje pozitivnog smjera korelacije koji ukazuje na to da je promjena varijable nasljeđa marke Chanel pozitivno povezana s promjenom varijable funkcionalne dimenzije percipirane vrijednosti marke Chanel od strane potrošača.

Rezultati korelacije između varijabli nasljeđa marke Chanel i emocionalne dimenzije percipirane vrijednosti marke Chanel pokazuju da je Spearmanov koeficijent korelacije (r) jednak 0.229, dok je značajnost koeficijenta korelacije (P) jednaka 0.022. S obzirom da je značajnost koeficijenta korelacije manja od 0.05, (P < 0.05), vidljiva je značajnost navedene korelacije, temeljem čega se može utvrditi povezanost varijabli nasljeđa marke Chanel i emocionalne dimenzije percipirane vrijednosti za potrošača navedene marke odnosno može se reći da je promjena varijable nasljeđa marke Chanel pozitivno povezana s promjenom emocionalne dimenzije percipirane vrijednosti marke Chanel. 
Rezultati korelacije između varijabli nasljeđa marke Chanel i ekonomske dimenzije percipirane vrijednosti marke Chanel pokazuju da je vrijednost Spearmanovog koeficijenta korelacije (r) jednaka - 0.170, što ukazuje na slabu negativnu povezanost nasljeđa s ekonomskom vrijednosti marke Chanel. Budući da je značajnost koeficijenta korelacije veća od 0.05, (P > 0.05), može se zaključiti da koeficijent korelacije nije statistički značajan te se ne može utvrditi postojanost i tumačiti povezanosti između varijabli nasljeđa marke Chanel i ekonomske dimenzije percipirane vrijednosti marke Chanel. Također, analiza pokazuje da korelacija između varijabli nasljeđa marke Chanel i njene socijalne dimenzije percipirane vrijednosti nije značajna odnosno ne može se utvrditi značajna povezanost između analiziranih varijabli.

Da bi se utvrdilo postoji li povezanost nasljeđa marke Bruno Banani i dimenzija percipirane vrijednosti za potrošača marke Bruno Banani, također je korištena neparametrijska analiza odnosno Spearmanov koeficijent korelacije. Navedena analiza izračunata je, također, u programu SPSS te su rezultati vidljivi u tablici 8.

Tablica 8. Rezultati korelacija između varijabla nasljeđa marke Bruno Banani i dimenzija percipirane vrijednosti potrošača za marku Bruno Banani

\begin{tabular}{|l|c|}
\hline Dimenzije vrijednosti & $\begin{array}{c}\text { Korelacija s nasljeđem } \\
\text { marke Bruno Banani }\end{array}$ \\
\hline Funkcionalna dimenzija vrijednosti marke Bruno Banani & $\mathrm{r}=0.130$ \\
$\mathrm{P}=0.196$ \\
$\mathrm{~N}=100$
\end{tabular}

Legenda: $\mathrm{r}$ - Spearmanov koeficijent korelacije, $* \mathrm{P}<0.05, * * \mathrm{P}<0.01$.

Izvor: rezultati istraživanja.

Rezultati korelacije između varijabli nasljeđa marke Bruno Banani i funkcionalne dimenzije percipirane vrijednosti marke Bruno Banani pokazuju da navedena korelacija nije značajna odnosno ne može se utvrditi signifikantna povezanost nasljeđa marke Bruno Banani i dimenzije funkcionalne percipirane vrijednosti marke Bruno Banani. Također, analiza pokazuje da korelacija između varijabli nasljeđa marke Bruno Banani i dimenzije njene socijalne percipirane vrijednosti nije značajna $(\mathrm{P}>0.05)$.

Analiza povezanosti nasljeđa marke Bruno Banani i ekonomske dimenzije percipirane vrijednosti navedene marke pokazuju da Spearmanov koeficijent korelacije (r) iznosi 0.369, dok značajnost koeficijenta korelacije (P) iznosi 0.000. Budući da je vrijednost koefi- 
cijenta korelacije niža od 0.01, (P < 0.01), može se zaključiti da je koeficijent korelacije statistički značajan odnosno postoji povezanost između varijabli nasljeđa marke Bruno Banani i ekonomske dimenzije percipirane vrijednosti marke Bruno Banani.

Nadalje, iz rezultata korelacije između varijabli nasljeđa marke Bruno Banani i emocionalne dimenzije percipirane vrijednosti za potrošača navedene marke vidljivo je da vrijednost Spearmanovog koeficijenta korelacije (r) iznosi 0.246. Značajnost koeficijenta korelacije ukazuje na postojanje povezanosti između varijabli nasljeđa marke Bruno Banani i emocionalne dimenzije percipirane vrijednosti marke Bruno Banani.

\section{ZAKLJUČAK}

Nasljeđe marke kao dio identiteta marke te njegova povezanost i utjecaj na dimenzije percipirane vrijednosti, kao i na samo ponašanje potrošača, relativno je novo područje istraživanja u sferi marketinga. Kao takvo, ono budi sve više i više interesa, tako da se posljednjih nekoliko godina povećao broj stranih istraživanja iz različitih industrija, poput automobilske industrije i industrije luksuznih dobara, koja su se bavila povezanošću nasljeđa marke i ponašanja potrošača. Upravo ta inozemna istraživanja poslužila su kao podloga ovome istraživanju u kojemu su stavljene u odnos dvije, $\mathrm{s}$ aspekta nasljeđa, različite marke iz industrije parfema te se željelo saznati pridaju li ispitanici navedenim markama elemente nasljeđa marke te postoji li povezanost nasljeđa marke i različitih dimenzija percipirane vrijednosti koje potrošači pridaju markama.

Provedeno istraživanje pokazalo da je ispitanici vrlo lako razlikuju marke s nasljeđem od marki bez nasljeđa. To je vidljivo iz rezultata koji potvrđuju kako ispitanici pridaju marki Chanel značajke, poput uspješnosti, snažnog kulturnog značenja, prepoznatljivosti u društvu, izvrsne reputacije i sličnih, koje su ujedno i sastavnice elemenata samog nasljeđa marke. Također, to se očituje i u rezultatima vezanima za nasljeđe marke Bruno Banani gdje joj ispitanici ne pridaju značajke vezane za nasljeđe marke odnosno ne smatraju da je odlikuje snažno kulturno nasljeđe, snažan identitet, niti jedinstvenost u odnosu na ostale marke parfema. Navedeni rezultati upućuju na velik značaj i prepoznatljivost bogatog nasljeđa od strane ispitanika kod marki koje ga posjeduju i koje ga uspješno komuniciraju.

Dio istraživanja vezan za percipirane vrijednosti potrošača donio je, također, zanimljive rezultate. Prema rezultatima, ispitanici smatraju da marka Chanel, to jest marka s nasljeđem, posjeduje izvanrednu kvalitetu i pouzdanost odnosno funkcionalna vrijednost za potrošače je visoka. Isto tako, ispitanici percipiraju visoku emocionalnu i socijalnu vrijednost marke s nasljeđem, pri čemu su najvišu razinu slaganja pokazali za tvrdnje vezane uz emocionalnu vrijednost. To znači da marka Chanel, kao marka s bogatim nasljeđem, izaziva snažne osjećaje kod potrošača. Zanimljivo je primijetiti da ispitanici marku Chanel vrjednuju kao visokokvalitetnu marku, no ipak smatraju da nije vrijedna svoje cijene, to jest može se reći da je precijenjena. S druge strane, ispitanici smatraju da marku parfema Bruno Banani odlikuje niža razina kvalitete, to jest funkcionalne vrijednosti, nego marku parfema Chanel. Također, stavovi potrošača o emocionalnoj i socijalnoj vrijednosti marke parfema Bruno Banani nalaze se, uglavnom, u neutralnome području. Ipak, za razliku od marke Chanel, ispitanici smatraju marku parfema Bruno Banani isplativom i vrijednom svoje cijene, to jest percipiraju visoku ekonomsku vrijednost te marke. 
Temeljem izračunatih korelacija kojima se željelo ispitati povezanost nasljeđa marke Chanel i dimenzija percipiranih vrijednosti navedene marke, došlo se do rezultata koji pokazuju pozitivnu povezanost nasljeđa marke Chanel i funkcionalne dimenzije percipirane vrijednosti te pozitivnu povezanost marke Chanel i emocionalne dimenzije percipirane vrijednosti za potrošača. Korelacije kojima se željelo ispitati povezanost nasljeđa marke Bruno Banani i dimenzija percipirane vrijednosti navedene marke pokazale su pozitivnu povezanost nasljeđa marke Bruno Banani i ekonomske dimenzije percipirane te pozitivnu povezanost nasljeđa marke Bruno Banani i emocionalne dimenzije vrijednosti za potrošača.

Može se zaključiti da su za marku s bogatim nasljeđem utvrđene veća funkcionalna, emocionalna i socijalna vrijednost u usporedbi s markom bez nasljeđa. Također, percipirano bogato nasljeđe marke pokazuje pozitivnu povezanost $\mathrm{s}$ funkcionalnom i emocionalnom dimenzijom percipirane vrijednosti marke, što znači da bi percipirano bogato nasljeđe marke moglo utjecati na percepciju kvalitete marke te emocionalnu povezanost s tom markom.

\section{OGRANIČENJA ISTRAŽIVANJA I PREPORUKE ZA BUDUĆA ISTRAŽIVANJA}

Potrebno je ukazati na ograničenja provedenoga istraživanja koja ujedno mogu biti i smjernice za buduća istraživanja. Istraživanje je provedeno za potrebe diplomskoga rada, a značajno ograničenje predstavlja mali uzorak ispitanika, što je onemogućilo provođenje složenijih statističkih analiza. Istraživanje bi bilo korisno provesti na većem broju ispitanika kako bi se dobio reprezentativan uzorak te sukladno tome analizirati i utjecaj i intenzitet utjecaja nasljeđa marke na dimenzije percipirane vrijednosti, a ne samo povezanost između tih varijabli. Također, $\mathrm{u}$ istraživanju su analizirane samo jedna marka s bogatim nasljeđem i jedna marka bez nasljeđa te bi buduća istraživanja svakako trebala uključiti više marki prilikom analize utjecaja nasljeđa marke na dimenzije percipirane vrijednosti u određenoj industriji. Obzirom na navedena ograničenja rezultati ovoga istraživanja trebaju se promatrati kao indikativni.

Za buduća istraživanja bilo bi korisno uvesti i komponentu kupovnog ponašanja potrošača te utvrditi njezinu povezanost s nasljeđem marke. Također, jedan od prijedloga je provesti slično istraživanje, ali u nekoj drugoj industriji, primjerice u industriji visoke tehnologije, kako bi se uvidjelo postoje li razlike u važnosti i odnosu nasljeđa marke i percipirane vrijednosti za potrošača. Na kraju, svako istraživanje na ovome području pomoći će razvitku općenite teorije o markama s nasljeđem, budući da je to područje još uvijek relativno novo i svakako nedovoljno istraženo u marketinškoj teoriji i praksi.

\section{LITERATURA:}

1. Aaker, D. A. (2004.), Leveraging the corporate brand, California Management Review, Vol. 46., No. 3, str. 10-16.

2. Aaker, D. A. (1996.), Building strong brands, New York: Free Press.

3. Abdolvand, M., Andervazh, L. (2011.), Investigating Customer Perceived Value in Custom Services, Asian Journal of Business Management Studies, Vol. 2, No. 4., str. 162-165. 
4. Ali, H. (2007.), Predicting the overall perceived value of leisure service: A survey of restaurant patrons in Pretoria, Magister's Thesis, University of Pretoria.

5. Baldinger, L., Rubinson J. (1996), Brand Loyalty: The Link Between Attitude and Behavior, Journal of Advertising Research, Vol. 36, No. 2, str. 22-34.

6. Baum, L. (2011.), The Communication of Heritage: How Swiss watch companies communicate their heritage on the Web site, Magister's Thesis, Aarhus University.

7. Dodds, W. B., Monroe, K. B., Grewal, D. (1991.), Effects of price, brand, and store information on buyers' products evaluations, Journal of Marketing Research, Vol. 28, No. 3, str. 307-319.

8. Khan, N., Kadir, A. (2011.), The impact of perceived value dimension on satisfaction and behavior intention: Young-adult consumers in banking industry, African Journal of Business Management ,Vol. 5, No. 11, str. 4087-4099.

9. Kotler, Ph., Keller K. L. (2008.), Upravljanje marketingom, 12. Izdanje, MATE Zagreb.

10. Lapierre, J. (2000.) Customere-perceived value in industrial contexts, Journal of Business \& Industrial Marketing, Vol. 15, No. 2/3, str. 122-140.

11. Li, J., Zhang, X., Sun, G. (2015.), Effects of „face“ consiousness on status consumption among chinese consumers: Percived social value as a mediator, Psychological Reports: Sociocultural Issues in Psychology, Vol. 116., No. 1, str. 280-291.

12. Liebrenz-Himes, M., Shamma, H., Dyer, R. (2007.), Heritage Brands, Treasured Inheritance or "Over the hill", CHARM, str. 140-143.

13. McDougall, G., Levesque, T. (2000.) Customer satisfaction with services: putting perceived value into the equation, Journal of Services Marketing, Vol. 14, No. 5, str. 392-410.

14. Moliner, M. A, Sanchez, J., Rodriguez, R. M, Callarisa, L. (2007.), Perceived relationship quality and post-purchase perceived value: an integrative framework, European Journal of Marketing, Vol. 41, No.11/12, str. 1392-1422.

15. Pandža Bajs, I. (2012.), Proces nastajanja percipirane vrijednosti s fokusom na čimbenike ponude poduzeća, Tržište, Vol. 24, No. 2, str. 279-296.

16. Piri Rajh, S. (2012.), Comparison of of Perceived Value Structural Models, Tržište, Vol. 24, No. 1, str. 117-133.

17. Roig, J., Sanchez, J. G., Tena, M., Monzonis, J., (2006.), Customer Perceived Value in Banking Services, International Journal of Bank Marketing, Vol. 24, No. 5, str. 266-283.

18. Sanchez, H., Callarisa, L., Rodrıguez, R. M., Moliner, M. A. (2006.) Perceived value of the purchase of a tourism product, Tourism Management, No. 27, str. 394-409.

19. Sheth, J. N., Newman, B. I., Gross, B. L. (1991.), Why We Buy What We Buy: A Theory of Consumption Values, Journal of Business Research, Vol. 22, No. 2, str. 159-170.

20. Smith, J., Colgate, M. (2007.), Customer value creation: A practical framework, Journal of Marketing Theory and Practice, Vol. 15, No. 1, str. 7-23.

21. Sunthorncheewin, S., Panichpathom, S., Ngarmyarn, A., Ratanaprichavej, N. (2013.), Investigating Home Buyer Loyalty through Satisfaction and Perceived Value Dimensions, International Journal of Scientific and Research Publications, Vol. 3, No. 12. 
22. Sweeney, J., Soutar, G., Johnson, L. (1999.), The Role of Perceived Risk in the Quality-Value Relationship, A study in a Retail Environment, Journal of Retailing, Vol. 75, No. 1, str. 77-105.

23. Sweeney, J., Soutar, G. (2001.), Consumer perceived value: The development of a multiple item scale, Journal of Retailing, Vol. 77, No. 2, str. 203-220.

24. Šapić, Š., Topalović, S., Marinković, V. (2014.), Uticaj dimenzija percipirane vrijednosti na lojalnost klijenata, Ekonomske teme, Vol. 52, No. 4, str. 401-417.

25. Urde, M., Greyser, S., Balmer, J. (2007.), Corporate brands with a Heritage, Journal palgrave, Brand management, Vol 15, No. 1, str. 5-17.

26. Vigneron, F., Johnson W. L. (2004.), Measuring Perceptions of Brand Luxury, Journal of Brand Management, str. 484-506.

27. Woodall, T. (2003.) Conceptualising 'Value for the Customer': An attributional, Structural and Disposional Analysis, Academy of Marketing Science Review, Vol. 2003, No. 12, str. 1-44.

28. Wuestefeld, T., Hennings, N., Schmidt, S., Wiedmann, K. P. (2012.), The impact of brand heritage on customer perceived value, in der markt - International Journal of Marketing, str. 2-12.

29. Wuestefeld, T., Hennings, N., Schmidt, S., Wiedmann, K. P. (2011.), Drivers and Outcomes of Brand Heritage: Consumers' Perception of Heritage Brands in the Automotive Industry, The Journal of Marketing Theory and Practice, No. 2, 19, str. 205-220.

30. Zeithaml, V. (1988.), Consumer Perceptions of Price, Quality, and Value: A Means-End Model and Synthesis of Evidence, Journal of Marketing, 52 (3), str. 2-22. 